\title{
Gender Differences in Chronic Kidney Disease: Underpinnings and Therapeutic Implications
}

\author{
Juan Jesús Carrero \\ Divisions of Renal Medicine and Baxter Novum, Department of Clinical Science, Intervention and Technology, \\ Centre for Molecular Medicine and Centre for Gender Medicine, Karolinska Institutet, Stockholm, Sweden
}

\section{Key Words}

Compliance $\cdot$ Estrogen $\cdot$ Testosterone

\begin{abstract}
In nephrology, gender differences exist with regard to the epidemiology, evolution and prognosis of chronic kidney disease (CKD). In some cases, these differences run contrary to the general population trends. This review discusses such gender and sex disparities, including differing impact of traditional and novel risk factors, prescription patterns, differences in the responses to therapies, as well as hormonal factors, all of them potentially influencing propensity, progression and biochemical and psychological aspects of CKD. Through the integration of gender aspects in CKD research and management, we may be able not only to identify novel therapeutic targets but also improve existing treatment options.

Copyright $\odot 2010$ S. Karger AG, Basel
\end{abstract}

\section{Introduction}

Although physicians often are forced to generalize treatment options and medical care, we cannot neglect that men and women are physiologically different. These differences are reflected in many varying aspects, with men and women diverging in the pathogenesis, clinical features and prognosis of many diseases. Moreover, diagnostic and therapeutic options are not necessarily identical. In recent years, gender-specific issues and how they influence health have increasingly attracted public attention, as well as interest from those working with healthcare and prevention. We have learned that gender is of great relevance not only in research but also in day-to-day medical practice. A clear example lies in the higher incidence of cardiovascular disease in men than in women of similar age, and the menopause-associated increase in cardiovascular disease in women. Compelling data have indicated that sex differences in vascular biology are determined not only by differences in sex steroid levels, but also by sex-specific tissue and cellular differences that mediate sex-specific responses, as well as lifestyle differences $[1,2]$.

Gender and sex are often used indistinctly and incorrectly in the scientific literature. For consistency throughout this review, some definitions should be stated a priori: by 'sex' we refer to the property or quality by which organisms are classified as female or male on the basis of their reproductive organs and functions; 'gender' refers, on the other hand, to the way in which people perceive themselves and how they expect others to behave, and is

\section{KARGER}

Fax +4161306 1234 E-Mail karger@karger.ch www.karger.com
(C) 2010 S. Karger AG, Basel

$1420-4096 / 10 / 0335-0383 \$ 26.00 / 0$

Accessible online at:

www.karger.com/kbr
Juan Jesús Carrero

Division of Renal Medicine, K56

Karolinska University Hospital at Huddinge

SE-141 86 Stockholm (Sweden)

Tel. +4685858 3982, Fax +4685858 3925, E-Mail juan.jesus.carrero@ki.se 
largely culturally determined. Therefore, sex-based differences are biologically based differences in men and women, whereas gender-based differences are distinctions shaped by the cultural and social environment (including differences in treatment prescriptions or disease perceptions) [3].

In nephrology, gender differences exist with regard to the epidemiology, evolution and prognosis of chronic kidney disease (CKD). In some cases, these differences run contrary to the general population trends. This review will present an overview of gender differences in CKD and also identify areas of overlap. Such gender dimorphism may involve differing impact of traditional risk factors and/or differences in the responses to therapies, as well as hormonal and genetic factors, all of them influencing propensity, progression and biochemical and psychological aspects of CKD. I will defend the thesis that through the integration of gender aspects in CKD research and management, we may be able not only to identify novel therapeutic targets but also improve existing treatment options. I will also try to show that there is still a gap between gender research and incorporation of the results into clinical practice.

\section{Sex Differences in Progression to End-Stage Renal Disease}

The progression rate of many renal diseases is affected by sex, and this is a topic excellently reviewed elsewhere in more detail [4]. The biggest meta-analysis to date, including more than 11,000 patients from 68 different studies, demonstrated that renal disease in women with polycystic kidney disease, IgA nephropathy, membranous glomerulopathy, and 'chronic renal disease of unknown aetiology' progresses at a slower rate than it does in blood pressure- and lipid levels-matched men with these diseases [5]. Recently, 2 additional population-based studies showed that men were associated with a worse CKD progression than women $[6,7]$. In another study [8] with 840 non-diabetic patients, the loss of renal function was slower in women than in men, especially in women who were younger and predominantly premenopausal. However, the difference in renal disease progression was no longer significant after adjusting for baseline proteinuria, mean arterial pressure, and high-density lipoprotein levels. A few studies have also observed a worse renal prognosis in women [9], but the fact that most women in such analyses were postmenopausal may explain the divergent findings. Fur- thermore, when the community-based PREVEND cohort [10] assessed which modifiable risk factors are associated with renal function decline, different results were found for men and women: in both men and women, plasma glucose and systolic blood pressure were independent risk predictors of renal function decline. Additionally in men, urinary albumin excretion was the strongest independent predictor of renal function decline, while low waist circumference and cholesterol/ HDL ratio were associated with a better renal function outcome; in women, on the other hand, low triglycerides were associated with better renal prognosis. Consistent with this, a previous study also from PREVEND suggested that risk factors such as age, BMI and plasma glucose contributed to exacerbate the male progression to end-stage renal disease (ESRD) to a greater extent than for comparable women [11]. Additionally, a sex-dimorphic adipokine, adiponectin, was associated with renal function decline in men, but not in women $[12,13]$. Altogether, there seem to be sex differences in the standard predictors of the decline in renal function, but little has been done with regard to whether these factors can be sex-specifically modified. Ahmed et al. [14] studied the renal plasma flow response in healthy humans to the nonspecific nitric oxide synthase inhibitor L-NAME. The authors observed that in men, the fall in renal plasma flow increased remarkably with increasing age, not observing such relationship in women. These results may suggest that any renal disease that interferes with nitric oxide production may, over time, cause existing kidney damage to progress more quickly in men relative to women.

Animal and experimental studies have tried to offer further mechanistic explanations for gender differences in disease progression. Besides the occurrence of sex specificities in kidney structure and glomerular hemodynamics [4], it has been suggested that the gender dimorphism of CKD progression may represent the effects of the interaction of circulating steroids with specific kidney receptors, an issue recently reviewed elsewhere [15]. Endogenous estrogens have in general been considered to have anti-fibrotic and anti-apoptotic effects on the kidney $[16,17]$. Consequently, $17 \beta$-estradiol administration in ovariectomized rats was shown to attenuate glomerulosclerosis and tubulointerstitial fibrosis [18], by protecting podocytes against injury through the upregulation of estrogen receptor $\beta$ in an animal model of type2 diabetes [19]. On the other hand, the faster kidney function decline in men has been attributed to the specific proapoptotic and profibrotic properties of andro- 
gens [17, 20, 21]. Recently, testosterone administration was shown to promote the apoptosis of proximal tubule kidney cells by direct regulation of the c-Jun amino terminal kinase [22].

Thus, a direct extrapolation from the animal studies above described would suggest that exogenous estrogen administration may slow ESRD progression. However, clinical evidence in this regard is conflicting. An observational study on premenopausal women found a strong association between oral contraceptive use and macroalbuminuria [23]. Supporting this observation, postmenopausal women on hormone replacement therapy had a significantly reduced risk of albuminuria in comparison with those not on hormone therapies [24], and type-2 diabetic proteinuric hypertensive women who received hormone replacement therapy had less proteinuria and higher creatinine clearance [25]. However, evidence exists to the contrary, as a large case-controlled study found that oral contraceptive use in premenopausal women or estrogen replacement therapy in postmenopausal women were both associated with increased risk of microalbuminuria [26]. Also, a recent retrospective study suggested an independent dose-dependent association of oral estrogen use and loss of kidney function in elderly women [27]. Clearly, the implications of these studies need to be carefully considered in the context of their observational and, in the majority of the cases, retrospective nature [28]. It should also be noted that, in general, hormone replacement therapy is prescribed less frequently to postmenopausal ESRD patients than to the general population [29], possibly creating a selection and under-representation bias.

A final reflection is required regarding creatinine clearance-based formulas for estimation of renal function. Although the variable sex is included in some but not all such estimations, they do not differentiate an athletic woman or a small, lean man. In a retrospective study, the Modification of Diet in Renal Disease Study equation-estimated glomerular filtration rate (MDRD-eGFR) was suggested to differ between sexes and to vary with age more than the serum creatinine concentration does [30]. Thus, it is possible that incorrect GFR estimation may over/underestimate renal function, perhaps influencing results from large epidemiological studies (inferring misclassification of CKD stage) and/or clinical decisions such as medication prescription. These are personal speculations and the author is not aware of studies addressing this possible sex difference. However, the reported higher prevalence on CKD stages 3-5 in females [31], which flies in the face of ESRD statistics where men are disproportionally affected (discussed below), may indeed depend on the limitations of the MDRD equation [31].

\section{Cancellation of Female Survival Advantage during Dialysis}

In the general population women have a longer life expectancy than men [32]. This may partly be explained by a lower prevalence of cardiovascular risk factors and events in women, who have also been found to have a longer life expectancy in populations with manifest atherosclerosis [33-36]. Likely because of the faster progression to ESRD in men, more men than women initiate dialysis $[5,10,11]$. Interestingly, men have somewhat higher eGFR at the start of dialysis compared to women [37-39], an issue that, although without apparent explanation, may link to gender differences in the physician's clinical judgment. However, once they start dialysis - and unlike in the general population - these women have as poor survival as men [40-42]. Interestingly, this cancelled survival advantage in ESRD women is not restored after transplantation [43]. This observation may be biased, however, by the fact that none of these studies differentiate between pre- and postmenopausal states. To the best of my knowledge, the reasons for this finding have not been fully investigated, while the explanation may increase our understanding of the causes and mechanisms of the increased mortality risk in ESRD. If so, they can potentially influence therapy.

An initial explanation for this cancellation of survival advantage would entitle the existence of sex differences to be included in risk factors upon dialysis initiation. In other words, a worse risk profile in woman starting dialysis would probably justify, to some extent, the similar mortality to men. However, evidence exists for the opposite, as we recently observed that incident dialysis men had a 2 -fold higher prevalence of cardiovascular disease and were more often smokers [42]. This worse risk profile would agree with the fact that in incident hemodialysis patients, men are more likely to develop left-ventricular hypertrophy [44]. Also, male gender predisposes to a higher risk of cardiovascular calcification on hemodialysis [45], while secondary hyperparathyroidism and adynamic bone disease (both linked to higher cardiovascular risk) are also reported to be more prevalent in male patients on dialysis $[46,47]$. However, and despite this evidence for a worse risk profile in men, both sexes die at an equal rate. Because, in 
agreement with the general population, women on hemodialysis present with increased leukocyte telomere length (a determinant of cell survival linked to cardiovascular disease and mortality [48]) as compared to men [49], this may suggest that the increased risk of women is not the result of a long-life risk exposure but rather a relatively short-term consequence of the disease/therapy. Interestingly, whereas a negative correlation between age and telomere length was reported in female hemodialysis patients, no such association was present in males, whose reduced telomere lengths seem to be more closely associated with inflammation [49]. Such results are in accordance with those by Fitzpatrick et al. [48], showing that in the general population CRP was associated with reduced telomere length in aged males, but not in matched females.

A following natural step towards an explanation is exploring whether the association of risk factors with mortality differs between sexes. In other words, the presence of certain risk factors may be more detrimental for women than for men, and vice versa [50]. For instance, women on dialysis have a higher incidence of gout, which is associated with increased cardiovascular risk [51]. By studying sex-specific differences, we could report on an interaction between sex and diabetes in hemodialysis patients, mediating excess mortality in women with concurrent diabetes [42]. Such findings are in line with reports in non-renal populations suggesting that diabetic women are at a higher mortality risk than diabetic men [52-54]. Also, a previous report on type 2 diabetic ESRD patients aged $\geq 60$ years showed a slightly increased mortality risk in women compared with men [41]. The exact mechanisms of this high risk in diabetic women remain unknown, but recent literature [52] has speculated that an increased prevalence of CVD risk factors in diabetic women combined with possible disparities in the level of medical care between the sexes may be important factors to explain such risk. Our study provides an example of the potential of assessing risk through a sex perspective, as it identifies a high-risk group of patients (diabetic ESRD women) that may warrant further investigation and benefit from intensified therapeutic care.

Another putative area of interest in explaining sex survival differences concerns the relation between inflammation, muscle mass and outcome [55]. Interestingly, this area of research consistently suggests certain protection from these derangements in women as compared to men. For instance, in the presence of inflammation (CRP $>10 \mathrm{mg} / \mathrm{l})$, men on dialysis seem to have a worse survival as compared to women with the same condition [56]. Markers of muscle strength and muscle mass were poor outcome predictors in women [57], signs of muscle atrophy are more commonly observed in women [58], and genetic variations in IL-1 gene, putatively associated to increased systemic inflammation, have been associated with poor nutritional status in men, but not in women [59]. Anorexia is one of the most common and early symptoms in the development of protein-energy wasting in CKD (partly due to systemic inflammation) which contributes to increased mortality, higher hospitalization rates, worse quality of life and depression [60, 61]. A sex-dimorphic pattern has been observed at this level, as anorectic women on hemodialysis exhibited a more favorable inflammatory and nutritional status than anorectic men [62], suggesting that uremic men may be more prone than women to inflammation-induced anorexia. In agreement with this, several studies have found sex differences in the regulation of appetite [63]. For instance, both feeding behavior during the ovarian hormone cycle and decreased food intake have been associated with elevated estradiol levels [64-66]. Also, higher anorectic signals and earlier satiety have been reported in men suffering from chronic illnesses $[67,68]$, perhaps contributing to a different response pattern to anorexigenic diseases (such as heart failure and cancer) among men and women [63]. Connected to this, megestrol acetate, a novel anorexigenic agent used in hemodialysis patients, has its origin in the chemical structure of sex hormones.

\section{Alterations in the Hypothalamic-Pituitary-Gonadal Axis}

The kidney is a potent endocrine organ, a key modulator of endocrine function and an important target for hormonal action. Thus, alterations in signal-feedback mechanisms and in production, transport, metabolism, elimination and protein binding of hormones rather commonly occur in this disease. As a direct consequence, the uremic state is associated with abnormalities in the synthesis or action of many hormones, including those in the hypothalamic-pituitary-gonadal axis [69]. Some of the differences above mentioned, while no data exists as yet, may relate to deficiencies at this level. Young uremic women usually experience premature menopause, approximately 4.5 years earlier on average than their non-uremic counterparts [70], and postmenopausal women on dialysis also have abnormally low serum 
estrogen levels [71]. Hypogonadism in women has been linked to sleep disorders, depression, urinary incontinence and, in the long term, to osteoporosis, impaired cognitive function and increased cardiovascular risk [70]. Interestingly, a recent report suggested that preeclampsia, a disorder of pregnancy characterized by elevated blood pressure and proteinuria, was a risk factor for the development of ESRD later in life [72], suggesting sex-specific factors that predispose to kidney failure. It is uncertain, however, whether these associations are explained by adverse effects of preeclampsia itself or by underlying risk factors that predispose women to both preeclampsia and later cardiovascular and renal disease. The atheroprotective effects of estrogen include alterations in serum lipids as well as modulation of bone health, adhesion molecules, pro-inflammatory cytokines and chemokines after endothelial injury, and may thereby protect blood vessels [73]. In this direction, persistent amenorrheic young women on dialysis had lower bone mineral density and evidence of increased bone resorption when compared with normal menstruating women on dialysis [74], and 1-year administration of the selective estrogen receptor modulator raloxifene, increased bone mineral density and decreased bone resorption markers and LDL-cholesterol values in postmenopausal hemodialysis women [75]. Also, genetic variations in the estrogen receptor $\alpha$ were associated with increased mortality in women starting dialysis [76]. Phenotypically, this group of patients presented with higher prevalence of protein-energy wasting, increased serum triglyceride, lower serum albumin and higher CRP concentrations [76]. Supporting this, megestrol acetate, an estrogen agonist, has successfully been used in ESRD patients as an effective therapy to treat proteinenergy wasting [77, 78]. However, a recent hypothesisgenerating review has suggested a possible increased risk of encapsulating peritoneal sclerosis (EPS) in women undergoing peritoneal dialysis [79]. Such hypothesis is based on experimental evidence suggesting that many cases of EPS have shown improvement with tamoxifen therapy, an antiestrogen compound [80]. Surprisingly, all except 1 of the larger EPS studies fail to report on sex distribution. The CKD literature counts with many EPS case reports and EPS case series, and clearly there is in those a higher prevalence of women, often premenopausal [79].

In men, I described above how some experimental studies associated testosterone with the faster male progression to ESRD. However, once the kidney function is lost, ESRD in men is characterized by a marked testos- terone deficiency, with this condition present in approximately $50 \%$ of patients on dialysis and substantial number of others at risk of deficiency [81]. Testosterone deficiency in ESRD is the result of reduced prolactin clearance [82], inhibition of luteinizing hormone signaling [83] and perhaps increased inflammation [84]. The consequences of uremic testosterone deficiency on sexual dysfunction [82] and anemia [85] have been explored in a few studies, but little attention has been given to the growing body of evidence suggesting that testosterone deficiency may contribute to the onset and progression of cardiovascular disease [86] and to the pro-catabolic environment of uremia [87]. Recently, low endogenous testosterone values in male hemodialysis patients were associated with increased risk of death [84, 88], and novel links between low testosterone values in ESRD patients and bone disorders [89] or endothelial activation [90] have been suggested. Despite this, there is limited quantitative evidence regarding the prevalence and consequences of a clinical condition of testosterone deficiency in men with ESRD. Whether restoration of testosterone levels or supraphysiological administration would diminish cardiovascular risk or improve nutritional status requires further investigation. Encouragingly, androgen therapy in uremic patients has resulted in amelioration of muscle mass, improved nutritional status [91, 92] and attenuated anemia [85], all of which could indirectly improve patient's cardiovascular risk $[93,94]$.

\section{Gender Differences in Dialysis Therapy, Adequacy and Patient Attitudes towards Disease}

Discrepancies in the response to medical or dialysis care between sexes may also contribute to the observed cancellation of the female survival advantage. The analysis of this issue should start by possible gender differences in attitude towards the disease, directly referring to the compliance with the dialysis treatment, medication and lifestyle restrictions. Needless to say, poor compliance dramatically increases the death hazards of dialysis patients [95]. Patient compliance is, however, hard to measure. Traditionally, routine clinical parameters like blood urea nitrogen (indicating protein intake), serum potassium (indicating potassium intake) and interdialytic weight gain (reflecting fluid and sodium intake) have been used [96]. This 'objective' patient compliance can be compared with the patient's perceived compliance, also called self-efficacy, and defined as 'the belief that one is 
capable of executing a given course of action'. In general, greater self-efficacy is thought to result in better compliance. In a Japanese study of chronic hemodialysis patients [97], the authors assessed gender differences in the relationship between self-efficacy and objective compliance, finding that female patients who had higher selfefficacy were less compliant. Interestingly, the association between self-efficacy and interdialytic weight gain was stronger for men than for women. There is evidence suggesting the existence of gender differences in stress and coping with the disease. Some studies suggest that women on dialysis feel higher stress than males in response to physical symptoms and disease status $[98,99]$. Additionally, it seems that more men than women rely on avoidance (smoking, irregular overeating and drinking) as means of coping with the stress of their illness [100]. These differences may translate into systemic stress, increased risk and further poor compliance, all likely increasing death hazards. Supporting this, women undergoing hemodialysis have been reported to experience a higher prevalence of depressive symptoms and anxiety traits $[101,102]$.

Various reports exemplify the need to take the patient's sex into account when taking medical decisions. It is evident that men and women differ in their responses to drug treatment as a result of physiological differences such as body weight, height, body surface area, total body water, and the amount of extracellular and intracellular water, as well as differences in pharmacokinetics or pharmacodynamics [103]. However, treatments are often universal and we seldom vary dosage according to the patient's sex. When prescribing dialysis, for instance, an overestimation of adequacy in women as estimated by $\mathrm{Kt} / \mathrm{V}$ has been suggested [104]. This overestimation is thought to result from sex limitations of the denominator of the formula (V, urea distribution volume) [105]. This issue may help to explain the surprising secondary observations from the HEMO study and others, which showed that women with $\mathrm{Kt} / \mathrm{V} \geq 1.53$ had a significantly lower mortality than those with Kt/V $\geq 1.16$, an effect opposite to that seen in comparable men [106-108]. In fact, when dialysis doses are recalculated in the HEMO study by applying body surface area instead of $\mathrm{V}$, such differences are much reduced [109].

Other studies have also demonstrated that women more often receive short dialysis $(<12 \mathrm{~h} /$ week) than men [110] or that women are less likely to receive arteriovenous fistulas (AVF) [111, 112]. Concerning the latter, some reports showing increased AVF failure in women $[113,114]$ may have created uncertainty on its use, despite an equal number of studies showing no gender difference, or the opposite $[115,116]$. A traditional fear of smaller vessels in women may have prevented some nephrologists from considering AVF in female patients. However, published data using duplex Doppler ultrasonography have demonstrated that vessel diameter does not differ among sexes [117]. Likely, surgical training is the key to both fistula placement and survival, as recent studies, almost a decade after the original observations, do not observe sex differences in AVF failure, perhaps reflecting an improvement in both technique and physician experience [118, 119]. Finally, sex differences exist with regard to hemoglobin and hematocrit due to factors such as sex hormones, iron utilization, and menstrual blood losses. [120]. Despite these differences in the general population, guidelines for the treatment of ESRD anemia suggest the same target for men and for women. Thus, it may not be surprising that previous studies have almost unanimously reported higher EPO resistance in women than in men. However, this resistance may be dependent upon menopause, since in premenopausal women, EPO resistance was explained by iron deficiency after menses [121].

\section{Summary and Conclusions}

Currently, scant attention is paid to the important biological and psychological differences between men and women with CKD. The author suggests that closer attention to sex and gender differences regarding progression of disease, risk factor inter-play, prescription patterns and patient attitudes towards the disease may help to elucidate novel pathways to benefit all CKD sufferers, as well as be of assistance in improving patient care. Clearly, there is a scarcity of information about the role of menopause in modifying risk profiling and the involvement of sex hormones in the disease. The fact that most CKD women are postmenopausal may have contributed to overlooking these issues. However, sex hormones still have a role after menopause and sexspecific tissue responses and cellular differences also exist [1].

Current knowledge shows us that CKD patients behave differently from the general population, lacking a female survival advantage during renal replacement therapy. When integrating the gender perspective in future studies in CKD patients, it is also important to keep in mind differences in medical care, including overestimation of dialysis dose. Undoubtedly, there is still plenty of 
work to be done on this topic, but it is the hope of the author that this review work will awaken some interest in what makes CKD men and women differ, especially as a means to improve patient outcome.

\section{Acknowledgements}

The author is indebted to his mentors and friends at Karolinska Institutet, patients, family and colleagues around the globe. Significant support is obtained by the Karolinska Institutet's Centre for Gender Medicine, as well as from the Swedish Kidney Association and the Loo and Hans Osterman's Foundation.

\section{References}

$\checkmark 1$ Vitale C, Mendelsohn ME, Rosano GM: Gender differences in the cardiovascular effect of sex hormones. Nat Rev Cardiol 2009; 6:532-542.

2 Lawlor DA, Ebrahim S, Davey Smith G: Sex matters: secular and geographical trends in sex differences in coronary heart disease mortality. BMJ 2001;323:541-545.

3 King BM: Opinion: a call for proper usage of 'gender' and 'sex' in biomedical publications. Am J Physiol Regul Integr Comp Physiol 2010;298:R1700-R1701.

-4 Silbiger S, Neugarten J: Gender and human chronic renal disease. Gend Med 2008; 5(suppl A):S3-S10.

5 Neugarten J, Acharya A, Silbiger SR: Effect of gender on the progression of nondiabetic renal disease: a meta-analysis. J Am Soc Nephrol 2000;11:319-329.

-6 Evans M, Fryzek JP, Elinder CG, Cohen SS, McLaughlin JK, Nyren O, Fored CM: The natural history of chronic renal failure: results from an unselected, population-based, inception cohort in Sweden. Am J Kidney Dis 2005;46:863-870.

7 Eriksen BO, Ingebretsen OC: The progression of chronic kidney disease: a 10 -year population-based study of the effects of gender and age. Kidney Int 2006;69:375-382.

-8 Coggins CH, Breyer Lewis J, Caggiula AW, Castaldo LS, Klahr S, Wang SR: Differences between women and men with chronic renal disease. Nephrol Dial Transplant 1998;13: 1430-1437.

-9 Jafar TH, Schmid CH, Stark PC, Toto R, Remuzzi G, Ruggenenti P, Marcantoni C, Becker G, Shahinfar S, De Jong PE, De Zeeuw D, Kamper AL, Strangaard S, Levey AS: The rate of progression of renal disease may not be slower in women compared with men: a patient-level meta-analysis. Nephrol Dial Transplant 2003;18:2047-2053.

- 10 Halbesma N, Brantsma AH, Bakker SJ, Jansen DF, Stolk RP, De Zeeuw D, De Jong PE, Gansevoort RT: Gender differences in predictors of the decline of renal function in the general population. Kidney Int 2008;74:505512.

-11 Verhave JC, Hillege HL, Burgerhof JG, Navis G, de Zeeuw D, de Jong PE: Cardiovascular risk factors are differently associated with urinary albumin excretion in men and women. J Am Soc Nephrol 2003;14:1330-1335.
12 Kollerits B, Fliser D, Heid IM, Ritz E, Kronenberg F: Gender-specific association of adiponectin as a predictor of progression of chronic kidney disease: the mild to moderate kidney disease study. Kidney Int 2007;71: 1279-1286.

13 Carrero JJ, Cordeiro AC, Lindholm B, Stenvinkel $\mathrm{P}$ : The emerging pleiotrophic role of adipokines in the uremic phenotype: current opinion in nephrology and hypertension 2010;19:37-42.

14 Ahmed SB, Fisher ND, Hollenberg NK: Gender and the renal nitric oxide synthase system in healthy humans. Clin J Am Soc Nephrol 2007;2:926-931.

15 Sandberg K: Mechanisms underlying sex differences in progressive renal disease. Gend Med 2008;5:10-23.

16 Stringer KD, Komers R, Osman SA, Oyama TT, Lindsley JN, Anderson S: Gender hormones and the progression of experimental polycystic kidney disease. Kidney Int 2005; 68:1729-1739.

17 Elliot SJ, Berho M, Korach K, Doublier S, Lupia E, Striker GE, Karl M: Gender-specific effects of endogenous testosterone: female alpha-estrogen receptor-deficient c57bl/6j mice develop glomerulosclerosis. Kidney Int 2007;72:464-472.

18 Maric C, Sandberg K, Hinojosa-Laborde C: Glomerulosclerosis and tubulointerstitial fibrosis are attenuated with 17beta-estradiol in the aging dahl salt sensitive rat. J Am Soc Nephrol 2004;15:1546-1556.

19 Catanuto P, Doublier S, Lupia E, Fornoni A, Berho M, Karl M, Striker GE, Xia X, Elliot S: 17 beta-estradiol and tamoxifen upregulate estrogen receptor beta expression and control podocyte signaling pathways in a model of type 2 diabetes. Kidney Int 2009;75:11941201.

20 Metcalfe PD, Leslie JA, Campbell MT, Meldrum DR, Hile KL, Meldrum KK: Testosterone exacerbates obstructive renal injury by stimulating TNF-alpha production and increasing proapoptotic and profibrotic signaling. Am J Physiol 2008;294:E435-E443.

21 Lu H, Lei X, Klaassen C: Gender differences in renal nuclear receptors and aryl hydrocarbon receptor in 5/6 nephrectomized rats. Kidney Int 2006;70:1920-1928.
22 Verzola D, Villaggio B, Procopio V, Gandolfo MT, Gianiorio F, Fama A, Tosetti F, Traverso P, Deferrari G, Garibotto G: Androgen-mediated apoptosis of kidney tubule cells: role of c-jun amino terminal kinase. Biochem Biophys Res Commun 2009;387:531-536.

23 Ahmed SB, Hovind P, Parving HH, Rossing P, Price DA, Laffel LM, Lansang MC, Stevanovic R, Fisher ND, Hollenberg NK: Oral contraceptives, angiotensin-dependent renal vasoconstriction, and risk of diabetic nephropathy. Diabetes Care 2005;28:19881994.

-24 Agarwal M, Selvan V, Freedman BI, Liu Y, Wagenknecht LE: The relationship between albuminuria and hormone therapy in postmenopausal women. Am J Kidney Dis 2005; 45:1019-1025.

25 Szekacs B, Vajo Z, Varbiro S, Kakucs R, Vaslaki L, Acs N, Mucsi I, Brinton EA: Postmenopausal hormone replacement improves proteinuria and impaired creatinine clearance in type 2 diabetes mellitus and hypertension. BJOG 2000;107:1017-1021.

26 Monster TB, Janssen WM, de Jong PE, de Jong-van den Berg LT: Oral contraceptive use and hormone replacement therapy are associated with microalbuminuria. Arch Intern Med 2001;161:2000-2005.

-27 Ahmed SB, Culleton BF, Tonelli M, Klarenbach SW, Macrae JM, Zhang J, Hemmelgarn BR: Oral estrogen therapy in postmenopausal women is associated with loss of kidney function. Kidney Int 2008;74:370376.

28 Silbiger S: The effects of hormone replacement therapy on renal function. Nat Clin Pract 2009;5:6-7.

29 Stehman-Breen CO, Gillen D, Gipson D: Prescription of hormone replacement therapy in postmenopausal women with renal failure. Kidney Int 1999;56:2243-2247.

30 Kallner A, Khatami Z: How does the MDRD study equation compare with serum creatinine in routine healthcare? Anatomy of MDRD-EGFR. Scand J Clin Lab Invest Suppl 2008;241:39-45.

31 Zoccali C, Kramer A, Jager KJ: Chronic kidney disease and end-stage renal disease: a review produced to contribute to the report 'The Status of Health in the European Union: Towards a Healthier Europe'. Nephrol Dial Transplant Plus 2009, in press. 
-32 Murray CJ, Lopez AD: Mortality by cause for eight regions of the world: global burden of disease study. Lancet 1997;349:1269-1276.

- 33 Wingard DL, Suarez L, Barrett-Connor E: The sex differential in mortality from all causes and ischemic heart disease. Am J Epidemiol 1983;117:165-172.

- 34 Kardys I, Vliegenthart R, Oudkerk M, Hofman A, Witteman JC: The female advantage in cardiovascular disease: do vascular beds contribute equally? Am J Epidemiol 2007; 166:403-412.

- 35 Isles CG, Hole DJ, Hawthorne VM, Lever AF: Relation between coronary risk and coronary mortality in women of the Renfrew and Paisley Survey: comparison with men. Lancet 1992;339:702-706.

-36 Tunstall-Pedoe H, Woodward M, Tavendale R, A'Brook R, McCluskey MK: Comparison of the prediction by 27 different factors of coronary heart disease and death in men and women of the Scottish heart health study: cohort study. BMJ 1997;315:722-729.

37 Stel VS, Tomson C, Ansell D, Casino FG, Collart F, Finne P, Ioannidis GA, De Meester J, Salomone M, Traynor JP, Zurriaga O, Jager $\mathrm{KJ}$ : Level of renal function in patients starting dialysis: an ERA-EDTA registry study. Nephrol Dial Transplant 2010, E-pub ahead of print.

-38 Obrador GT, Arora P, Kausz AT, Ruthazer R, Pereira BJ, Levey AS: Level of renal function at the initiation of dialysis in the US: endstage renal disease population. Kidney Int 1999;56:2227-2235.

- 39 Traynor JP, Simpson K, Geddes CC, Deighan CJ, Fox JG: Early initiation of dialysis fails to prolong survival in patients with end-stage renal failure. J Am Soc Nephrol 2002;13: 2125-2132.

-40 Villar E, Remontet L, Labeeuw M, Ecochard R: Effect of age, gender, and diabetes on excess death in end-stage renal failure. J Am Soc Nephrol 2007; 18:2125-2134

-41 Villar E, Chang SH, McDonald SP: Incidences, treatments, outcomes, and sex effect on survival in patients with end-stage renal disease by diabetes status in Australia and New Zealand (1991-2005). Diabetes Care 2007; 30:3070-3076.

42 Carrero JJ, de Mutsert R, Axelsson J, Dekkers OM, Jager KJ, Boeschoten EW, Krediet RT, Dekker FW: Sex differences in the impact of diabetes on mortality in chronic dialysis patients. Nephrol Dial Transplant 2010, E-pub ahead of print

-43 Oien CM, Reisaeter AV, Os I, Jardine A, Fellstrom $\mathrm{B}$, Holdaas $\mathrm{H}$ : Gender-associated risk factors for cardiac end points and total mortality after renal transplantation: post hoc analysis of the alert study. Clin Transplant 2006;20:374-382.

-44 Foley RN, Curtis BM, Randell EW, Parfrey PS: Left ventricular hypertrophy in new hemodialysis patients without symptomatic cardiac disease. Clin J Am Soc Nephrol 2010; 5:805-813.
45 Schlieper G, Brandenburg V, Djuric Z, Damjanovic T, Markovic N, Schurgers L, Kruger T, Westenfeld R, Ackermann D, Haselhuhn A, Dimkovic S, Ketteler M, Floege J, Dimkovic N: Risk factors for cardiovascular calcifications in non-diabetic caucasian haemodialysis patients. Kidney Blood Press Res 2009;32:161-168.

46 Spasovski GB, Bervoets AR, Behets GJ, Ivanovski N, Sikole A, Dams G, Couttenye MM, De Broe ME, D'Haese PC: Spectrum of renal bone disease in end-stage renal failure patients not yet on dialysis. Nephrol Dial Transplant 2003;18:1159-1166.

47 Malberti F, Marcelli D, Conte F, Limido A, Spotti D, Locatelli F: Parathyroidectomy in patients on renal replacement therapy: an epidemiologic study. J Am Soc Nephrol 2001; 12:1242-1248

48 Fitzpatrick AL, Kronmal RA, Gardner JP, Psaty BM, Jenny NS, Tracy RP, Walston J, Kimura M, Aviv A: Leukocyte telomere length and cardiovascular disease in the cardiovascular health study. Am J Epidemiol 2007;165:14-21.

49 Carrero JJ, Stenvinkel P, Fellstrom B, Qureshi AR, Lamb K, Heimburger O, Barany P, Radhakrishnan K, Lindholm B, Soveri I, Nordfors L, Shiels PG: Telomere attrition is associated with inflammation, low fetuina levels and high mortality in prevalent haemodialysis patients. J Intern Med 2008;263: 302-312.

50 Carrero JJ, Stenvinkel P: Persistent inflammation as a catalyst for other risk factors in chronic kidney disease: a hypothesis proposal. Clin J Am Soc Nephrol 2009;4(supp 1):S49-S55.

51 Cohen SD, Kimmel PL, Neff R, Agodoa L, Abbott KC: Association of incident gout and mortality in dialysis patients. J Am Soc Nephrol 2008;19:2204-2210.

52 Huxley R, Barzi F, Woodward M: Excess risk of fatal coronary heart disease associated with diabetes in men and women: metaanalysis of 37 prospective cohort studies. BMJ 2006;332:73-78.

53 Barrett-Connor E, Wingard DL: Sex differential in ischemic heart disease mortality in diabetics: a prospective population-based study. Am J Epidemiol 1983;118:489-496.

54 Scheidt-Nave C, Barrett-Connor E, Wingard DL, Cohn BA, Edelstein SL: Sex differences in fasting glycemia as a risk factor for ischemic heart disease death. Am J Epidemiol 1991;133:565-576.

55 Carrero JJ, Yilmaz MI, Lindholm B, Stenvinkel P: Cytokine dysregulation in chronic kidney disease: how can we treat it? Blood Purif 2008;26:291-299.

56 Stenvinkel P, Wanner C, Metzger T, Heimburger O, Mallamaci F, Tripepi G, Malatino L, Zoccali C: Inflammation and outcome in end-stage renal failure: does female gender constitute a survival advantage? Kidney Int 2002;62:1791-1798.
57 Stenvinkel P, Barany P, Chung SH, Lindholm B, Heimburger O: A comparative analysis of nutritional parameters as predictors of outcome in male and female ESRD patients. Nephrol Dial Transplant 2002;17:12661274.

58 Carrero JJ, Chmielewski M, Axelsson J, Snaedal S, Heimburger O, Barany P, Suliman ME, Lindholm B, Stenvinkel P, Qureshi AR: Muscle atrophy, inflammation and clinical outcome in incident and prevalent dialysis patients. Clin Nutr 2008;27:557-564.

-59 Maruyama Y, Nordfors L, Stenvinkel P, Heimburger O, Barany P, Pecoits-Filho R, Axelsson J, Hoff CM, Holmes CJ, Schalling $\mathrm{M}$, Lindholm B: Interleukin-1 gene cluster polymorphisms are associated with nutritional status and inflammation in patients with end-stage renal disease. Blood Purif 2005:23:384-393

-60 Carrero JJ, Aguilera A, Stenvinkel P, Gil F, Selgas R, Lindholm B: Appetite disorders in uremia. J Ren Nutr 2008;18:107-113.

61 Carrero JJ: Identification of patients with eating disorders: clinical and biochemical signs of appetite loss in dialysis patients. J Ren Nutr 2009;19:10-15.

62 Carrero JJ, Qureshi AR, Axelsson J, Avesani CM, Suliman ME, Kato S, Barany P, SnaedalJonsdottir S, Alvestrand A, Heimburger O, Lindholm B, Stenvinkel P: Comparison of nutritional and inflammatory markers in dialysis patients with reduced appetite. Am J Clin Nutr 2007;85:695-701.

63 Geary N: Sex differences in disease anorexia. Nutrition 2001;17:499-507.

64 Lyons PM, Truswell AS, Mira M, Vizzard J, Abraham SF: Reduction of food intake in the ovulatory phase of the menstrual cycle. Am J Clin Nutr 1989;49:1164-1168.

65 Li ET, Tsang LB, Lui SS: Menstrual cycle and voluntary food intake in young Chinese women. Appetite 1999;33:109-118.

-66 Barr SI, Janelle KC, Prior JC: Energy intakes are higher during the luteal phase of ovulatory menstrual cycles. Am J Clin Nutr 1995; 61:39-43.

67 Intebi AD, Garau L, Brusco I, Pagano M, Gaillard RC, Spinedi E: Alzheimer's disease patients display gender dimorphism in circulating anorectic adipokines. Neuroimmunomodulation 2002;10:351-358.

68 Walsh D, Donnelly S, Rybicki L: The symptoms of advanced cancer: relationship to age, gender, and performance status in 1,000 patients. Support Care Cancer 2000;8:175-179.

69 Carrero JJ, Qureshi AR, Axelsson J, Yilmaz MI, Rehnmark S, Witt MR, Barany P, Heimburger O, Suliman ME, Alvestrand A, Lindholm B, Stenvinkel P: Clinical and biochemical implications of low thyroid hormone levels (total and free forms) in euthyroid patients with chronic kidney disease. J Intern Med 2007;262:690-701. 
-70 Weisinger JR, Bellorin-Font E: Outcomes associated with hypogonadism in women with chronic kidney disease. Adv Chron Kidney Dis 2004;11:361-370.

-71 Kramer HM, Curhan G, Singh A: Hemodialysis and estrogen levels in postmenopausal (HELP) patients: The Multicenter HELP Study. Am J Kidney Dis 2003;41:1240-1246.

-72 Vikse BE, Irgens LM, Leivestad T, Skjaerven $\mathrm{R}$, Iversen BM: Preeclampsia and the risk of end-stage renal disease. N Engl J Med 2008; 359:800-809.

-73 Mendelsohn ME, Karas RH: Molecular and cellular basis of cardiovascular gender differences. Science 2005;308:1583-1587.

- 74 Weisinger JR, Gonzalez L, Alvarez H, Hernandez E, Carlini RG, Capriles F, Cervino M, Martinis R, Paz-Martinez V, Bellorin-Font E: Role of persistent amenorrhea in bone mineral metabolism of young hemodialyzed women. Kidney Int 2000;58:331-335.

-75 Hernandez E, Valera R, Alonzo E, BajaresLilue M, Carlini R, Capriles F, Martinis R, Bellorin-Font E, Weisinger JR: Effects of raloxifene on bone metabolism and serum lipids in postmenopausal women on chronic hemodialysis. Kidney Int 2003;63:22692274.

-76 Kato S, Lindholm B, Axelsson J, Qureshi RA, Barany P, Heimburger O, Gustafsson JA, Stenvinkel P, Nordfors L: Association between oestrogen receptor alpha gene polymorphism and mortality in female end-stage renal disease patients. Nephrol Dial Transplant 2007;22:2571-2577.

-77 Rammohan M, Kalantar-Zadeh K, Liang A, Ghossein C: Megestrol acetate in a moderate dose for the treatment of malnutrition-inflammation complex in maintenance dialysis patients. J Ren Nutr 2005; 15:345-355.

-78 Monfared A, Heidarzadeh A, Ghaffari M, Akbarpour M: Effect of megestrol acetate on serum albumin level in malnourished dialysis patients. J Ren Nutr 2009;19:167-171.

79 Guest S: Hypothesis: gender and encapsulating peritoneal sclerosis. Perit Dial Int 2009; 29:489-491.

-80 Guest S: Tamoxifen therapy for encapsulating peritoneal sclerosis: mechanism of action and update on clinical experiences. Perit Dial Int 2009;29:252-255.

81 Carrero JJ, Qureshi AR, Nakashima A, Arver S, Parini P, Lindholm B, Barany P, Heimburger O, Stenvinkel P: Prevalence and clinical implications of testosterone deficiency in men with end-stage renal disease. Nephrol Dial Transplant 2010, in press.

-82 Palmer BF: Outcomes associated with hypogonadism in men with chronic kidney disease. Adv Chron Kidney Dis 2004;11:342347.

-83 Dunkel L, Raivio T, Laine J, Holmberg C: Circulating luteinizing hormone receptor inhibitor(s) in boys with chronic renal failure. Kidney Int 1997;51:777-784.
84 Carrero JJ, Qureshi AR, Parini P, Arver S, Lindholm B, Barany P, Heimburger O, Stenvinkel $P$ : Low serum testosterone increases mortality risk among male dialysis patients. J Am Soc Nephrol 2009;20:613-620.

85 Brockenbrough AT, Dittrich MO, Page ST, Smith T, Stivelman JC, Bremner WJ: Transdermal androgen therapy to augment EPO in the treatment of anemia of chronic renal disease. Am J Kidney Dis 2006;47:251-262.

86 Traish AM, Saad F, Feeley RJ, Guay A: The dark side of testosterone deficiency. III. Cardiovascular disease. J Androl 2009;30:477494.

87 Johansen KL: Anabolic and catabolic mechanisms in end-stage renal disease. Adv Chron Kidney Dis 2009;16:501-510.

88 Gungor O, Kircelli F, Juan Jesus C, Asci G, Toz H, Tatar E, Hur E, Sever MS, Arinsoy T, Ok E: Endogenous testosterone and mortality in male hemodialysis patients: is it the result of aging? Clin J Am Soc Nephrol 2010, in press.

89 Doumouchtsis KK, Kostakis AI, Doumouchtsis SK, Grapsa EI, Passalidou IA, Tziamalis MP, Poulakou MV, Vlachos IS, Perrea DN: The effect of sexual hormone abnormalities on proximal femur bone mineral density in hemodialysis patients and the possible role of rankl. Hemodial Int 2008; 12 : 100-107.

90 Karakitsos D, Patrianakos AP, De Groot E, Boletis J, Karabinis A, Kyriazis J, Samonis G, Parthenakis FI, Vardas PE, Daphnis E: Androgen deficiency and endothelial dysfunction in men with end-stage kidney disease receiving maintenance hemodialysis. Am J Nephrol 2006;26:536-543.

91 Johansen KL, Painter PL, Sakkas GK, Gordon P, Doyle J, Shubert T: Effects of resistance exercise training and nandrolone decanoate on body composition and muscle function among patients who receive hemodialysis: a randomized, controlled trial. J Am Soc Nephrol 2006;17:2307-2314

92 Johansen KL, Mulligan K, Schambelan M: Anabolic effects of nandrolone decanoate in patients receiving dialysis: a randomized controlled trial. JAMA 1999;281:1275-1281.

93 Avesani CM, Carrero JJ, Axelsson J, Qureshi AR, Lindholm B, Stenvinkel P: Inflammation and wasting in chronic kidney disease: partners in crime. Kidney Int Suppl 2006:S8S13.

94 Chmielewski M, Carrero JJ, Stenvinkel P, Lindholm B: Metabolic abnormalities in chronic kidney disease that contribute to cardiovascular disease, and nutritional initiatives that may diminish the risk. Curr Opin Lipidol 2009;20:3-9.

-95 Saran R, Bragg-Gresham JL, Rayner HC, Goodkin DA, Keen ML, Van Dijk PC, Kurokawa K, Piera L, Saito A, Fukuhara S, Young EW, Held PJ, Port FK: Nonadherence in hemodialysis: associations with mortality, hospitalization, and practice patterns in the DOPPS. Kidney Int 2003;64:254-262.
96 Kaveh K, Kimmel PL: Compliance in hemodialysis patients: multidimensional measures in search of a gold standard. Am J Kidney Dis 2001;37:244-266.

-97 Takaki J, Yano E: Possible gender differences in the relationships of self-efficacy and the internal locus of control with compliance in hemodialysis patients. Behav Med 2006;32:5-11.

98 Yeh SJ, Huang C, Chou H, Wan TTH: Gender differences in stress and coping among elderly patients on hemodialysis. Sex Roles 2009;60:44-56.

99 Lindqvist R, Carlsson M, Sjoden PO: Coping strategies and quality of life among patients on hemodialysis and continuous ambulatory peritoneal dialysis. Scand J Caring Sci 1998;12:223-230.

100 Yeh SC, Chou HC: Coping strategies and stressors in patients with hemodialysis. Psychosom Med 2007;69:182-190.

101 Vazquez I, Valderrabano F, Fort J, Jofre R, Lopez-Gomez JM, Moreno F, Sanz-Guajardo D: Gender differences in health-related quality of life in hemodialysis patients. Nefrologia 2004;XXIV:167-178

102 Lopes GB, Matos CM, Leite EB, Martins MT, Martins MS, Silva LF, Robinson BM, Port FK, James SA, Lopes AA: Depression as a potential explanation for gender differences in health-related quality of life among patients on maintenance hemodialysis. Nephron Clin Pract 2010;115:c35-c40.

103 Soldin OP, Mattison DR: Sex differences in pharmacokinetics and pharmacodynamics. Clin Pharmacokinet 2009;48:143-157.

104 Spalding EM, Chandna SM, Davenport A, Farrington $\mathrm{K}: \mathrm{Kt} / \mathrm{V}$ underestimates the hemodialysis dose in women and small men. Kidney Int 2008;74:348-355.

105 Daugirdas JT, Depner TA, Greene T, Kuhlmann MK, Levin NW, Chertow GM, Rocco MV: Surface-area-normalized Kt/V: a method of rescaling dialysis dose to body surface area - implications for differentsize patients by gender. Semin Dial 2008;21: 415-421.

106 Eknoyan G, Beck GJ, Cheung AK, Daugirdas JT, Greene T, Kusek JW, Allon M, Bailey J, Delmez JA, Depner TA, Dwyer JT, Levey AS, Levin NW, Milford E, Ornt DB, Rocco MV, Schulman G, Schwab SJ, Teehan BP, Toto R: Effect of dialysis dose and membrane flux in maintenance hemodialysis. $\mathrm{N}$ Engl J Med 2002;347:2010-2019.

107 Depner T, Daugirdas J, Greene T, Allon M, Beck G, Chumlea C, Delmez J, Gotch F, Kusek J, Levin N, Macon E, Milford E, Owen W, Star R, Toto R, Eknoyan G: Dialysis dose and the effect of gender and body size on outcome in the hemo study. Kidney Int 2004;65:1386-1394

108 Port FK, Wolfe RA, Hulbert-Shearon TE, McCullough KP, Ashby VB, Held PJ: High dialysis dose is associated with lower mortality among women but not among men. Am J Kidney Dis 2004;43:1014-1023. 
109 Daugirdas JT, Greene T, Chertow GM, Depner TA: Can rescaling dose of dialysis to body surface area in the hemo study explain the different responses to dose in women versus men? Clin J Am Soc Nephrol 2010 , in press.

110 Couchoud C, Kooman J, Finne P, Leivestad T, Stojceva-Taneva O, Ponikvar JB, Collart F, Kramar R, de Francisco A, Jager KJ: From registry data collection to international comparisons: examples of haemodialysis duration and frequency. Nephrol Dial Transplant 2009;24:217-224.

111 Miller CD, Robbin ML, Allon M: Gender differences in outcomes of arteriovenous fistulas in hemodialysis patients. Kidney Int 2003;63:346-352.

112 Wasse H, Hopson SD, McClellan W: Racial and gender differences in arteriovenous fistula use among incident hemodialysis patients. Am J Nephrol 2010;32:234-241.
13 Rayner HC, Pisoni RL, Gillespie BW, Goodkin DA, Akiba T, Akizawa T, Saito A, Young EW, Port FK: Creation, cannulation and survival of arteriovenous fistulae: data from the dialysis outcomes and practice patterns study. Kidney Int 2003;63:323330.

114 Vernaglione L, Mele G, Cristofano C, Distratis C, Perrone F, Frascina M, Pennacchiotti F, Chimienti S: Comorbid conditions and gender impact the primary survival of distal radio-cephalic arteriovenous fistula inpatients on long-term hemodialysis. J Nephrol 2005;18:276-281.

115 Puskar D, Pasini J, Savic I, Bedalov G, Sonicki Z: Survival of primary arteriovenous fistula in 463 patients on chronic hemodialysis. Croat Med J 2002;43:306-311.

116 Erkut B, Unlu Y, Ceviz M, Becit N, Ates A, Colak A, Kocak H: Primary arteriovenous fistulas in the forearm for hemodialysis: effect of miscellaneous factors in fistula patency. Ren Fail 2006;28:275-281.
17 Caplin N, Sedlacek M, Teodorescu V, Falk A, Uribarri J: Venous access: women are equal. Am J Kidney Dis 2003;41:429-432.

118 Saran R, Elder SJ, Goodkin DA, Akiba T, Ethier J, Rayner HC, Saito A, Young EW, Gillespie BW, Merion RM, Pisoni RL: Enhanced training in vascular access creation predicts arteriovenous fistula placement and patency in hemodialysis patients: results from the dialysis outcomes and practice patterns study. Ann Surg 2008;247: 885-891.

119 Shenoy S: Surgical anatomy of upper arm: what is needed for AVF planning. J Vasc Access 2009;10:223-232.

120 Rushton DH, Barth JH: What is the evidence for gender differences in ferritin and haemoglobin? Crit Rev Oncol Hematol 2010;73:1-9.

121 Di Iorio BR, Stellato D, De Santo NG, Cirillo M: Association of gender and age with erythropoietin resistance in hemodialysis patients: role of menstrual status. Blood Purif 2004;22:423-427. 